\title{
A review of the ecology and status of white whales (Delphinapterus leucas) in Svalbard, Norway
}

\author{
Christian Lydersen \& Kit M. Kovacs \\ Norwegian Polar Institute, Fram Centre, Tromsø, Norway
}

\begin{abstract}
The Norwegian Polar Institute initiated a research programme on white whales in 1995 to gather biological information relevant for the species' management; the results of which are reviewed herein. Satellite tracking from two periods (19952001 and 2013-16), between which sea ice diminished markedly, showed that the whales in waters off the archipelago of Svalbard spent most of their time foraging close to tidewater glaciers. Transits between glaciers typically followed the coastline, with the whales moving rapidly from one glacier to another. During the later period, the whales spent some time out in the fjords, suggesting that they might be targeting prey in the Atlantic Water masses that now prevail in Svalbard's westcoast fjords. Most of their dives were extremely shallow (13 \pm 26 m; maximum 350 $\mathrm{m})$ and of short duration $(97 \pm 123 \mathrm{~s}$; maximum $31.4 \mathrm{~min})$. Fatty-acid analyses indicated that polar cod (Boreogadus saida) was the main prey during the first sampling period. An aerial survey in 2018 estimated the population numbered 549 (CI: 436-723) animals. Svalbard white whales are genetically separate from populations off west Greenland and in the White Sea. Predation by killer whales appears to have influenced white whale behaviour in Svalbard; they are often silent, despite having a normal vocal repertoire for the species and their coastal movements take place in very shallow water. This population has extremely high contaminant levels. Climate change poses a threat to this small population of white whales.
\end{abstract}

This article is part of the special cluster Beluga whales (Delphinapterus leucas): knowledge from the wild, human care and TEK, which has been funded by Mystic Aquarium, CAFF and the Norwegian Ministry of Climate and Environment.

\section{Introduction}

The Svalbard Archipelago was discovered by Willem Barentsz in 1596, and the first commercial whaling enterprise commenced the year following. Initially, harvests were focused on bowhead whales (Balaena mysticetus). When their numbers declined, marine mammal harvests diversified in the archipelago, with polar bears (Ursus maritimus), walruses (Odobenus rosmarus) and seals being targeted. Russian whalers began harvesting white whales (Delphinapterus leucas) in the area early in the 17th century, mainly operating in the fjords on the west coast of Spitsbergen. Documentation of these early catches is sparse. However, one crew wintering at the southernmost tip of Spitsbergen reported taking about 1200 whales in 1818 (Isachsen 1921). Norwegians joined in the fishery for white whales in Svalbard in 1866 and continued harvesting until whaling ended in the early 1960s, when the species became protected in Svalbard. At this time, the

\section{Keywords}

Abundance; beluga; climate change; genetics; tracking; pollution

\section{Correspondence}

Christian Lydersen, Norwegian Polar Institute, PO Box 6606 Langnes, NO-9296 Tromsø, Norway. E-mail: christian.lydersen@ npolar.no

Abbreviations:
Cl: confidence interval
CTD: conductivity-temperature-depth
max: maximum
min: minimum
POP: persistent organic pollutant

Abbreviations:

POP: persistent organic pollutant

population was described as being severely depleted and 'commercially extinct' (Gjertz \& Wiig 1994). In total, about 15000 whales were landed in documented catches (Lønø \& Øynes 1961; Gjertz \& Wiig 1994).

Despite the fact that white whales are resident in Svalbard and were hunted for an extended period, very little was known about the ecology and biology of these whales in Norwegian waters until quite recently. The Norwegian Polar Institute initiated the first field-based research programme on white whales in 1995, with the objective of gathering biological information relevant to the management of this species in Svalbard. Because white whales are protected in the archipelago, research was restricted to observational studies, minimally invasive instrumentation, and collection of tissues from live animals. The first white whales were live-captured for scientific purposes in 1995, and since then, white whales have been part of the Norwegian Polar Institute's biodiversity programme, with field campaigns occurring at irregular intervals. Most expeditions have been undertaken using a 
sailboat 'camp' with two towed zodiacs for search and capture activities. A few larger-scale expeditions (survey work or late-season capture activities) have been undertaken with ship support. When animals were encountered, the fivesix-person research team used shore-anchored nets to live-capture whales. A total of 76 white whales have been caught, and tissue samples have been collected for various studies from all these animals; 38 of these whales have been instrumented with biologging devices. Results from these studies of the ecology and status of white whales in the Svalbard Archipelago are summarized herein.

\section{Tracking studies}

White whales in Svalbard have been instrumented with various types of satellite relayed data loggers (Fig. 1) produced by the Sea Mammal Research Unit, University of St Andrews, during two research programme periods (1995-2001 and 2013-16). Thirty-eight individuals have been instrumented, resulting in a total of 2055 tracking

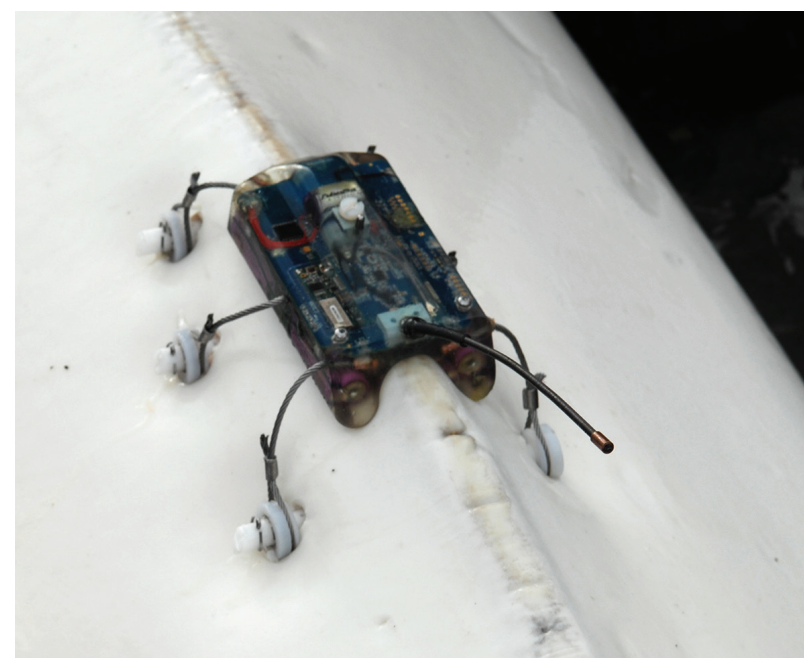

Fig. 1 Sea Mammal Research Unit's (University of St Andrews, Scotland) satellite-relayed data loggers fitted to the dorsal ridge of adult male white whales in Svalbard. Through the Argos satellite system, the loggers relay data on position, dive depth and duration and measure temperature in the water column the whales dive through.

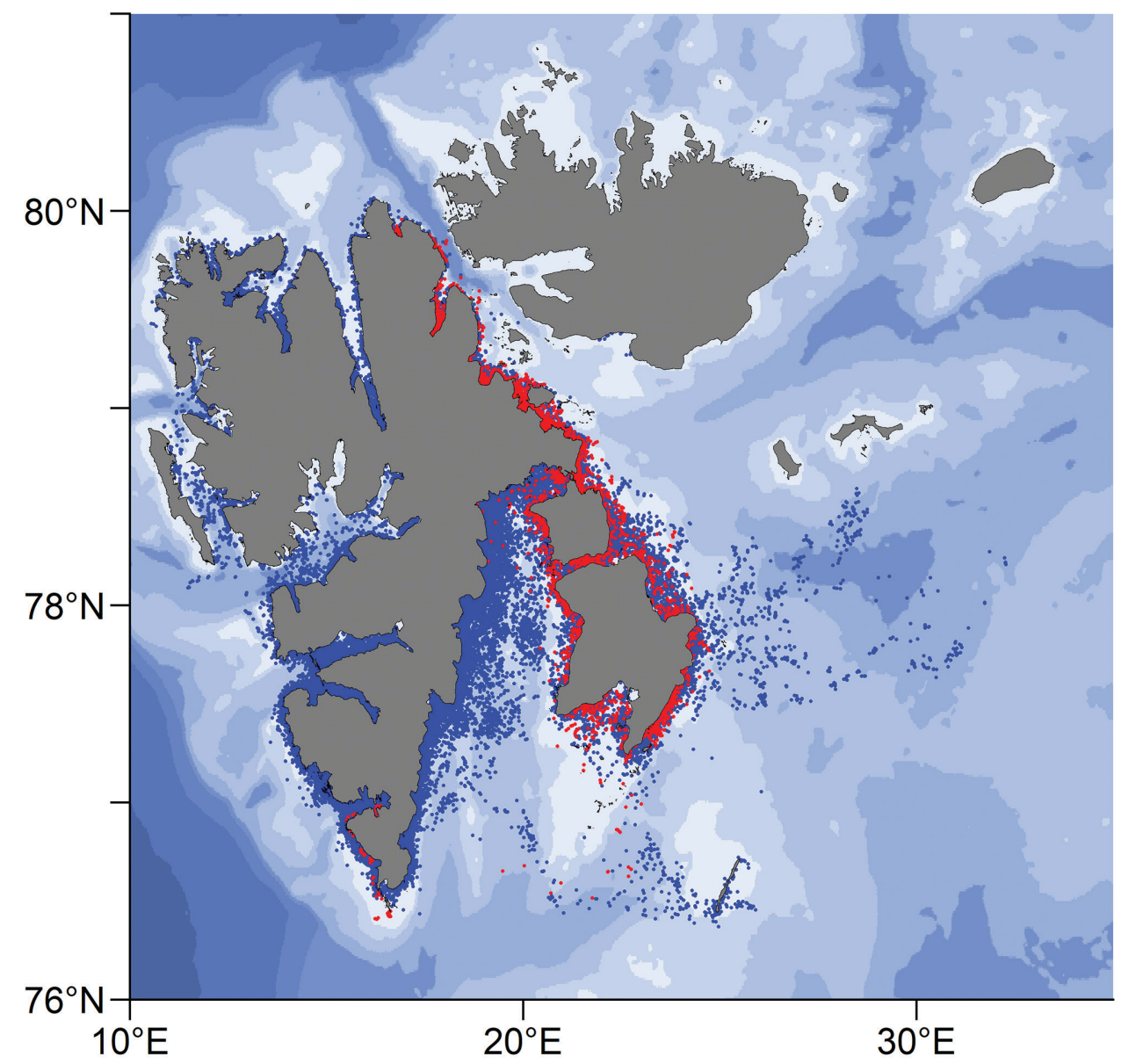

Fig. 2 Map showing all positions received from tracking studies of white whales in Svalbard. Location points are from 1897 tracking days for 34 males (blue dots) and 158 tracking days for four females (red dots). 
days (Fig. 2). The first published work from these efforts was based on 15 adult whales (14 males and one female) instrumented during the summer seasons from 1995 to 1999 (Lydersen et al. 2001). The whales spent most of their time $(55.6 \%)$ close to tidewater glacier fronts. Such areas are known to have high abundances of fish and invertebrates (Lydersen et al. 2014), so it was assumed that these areas were key foraging sites. The whales moved from one glacier front to another in a rapid and directed manner, staying very close to shore in shallow waters. Although killer whales (Orcinus orca) are not particularly common in Svalbard currently (Storrie et al. 2018), the behaviour of Svalbard white whales during transits between glacier fronts is similar to responses to the presence of this predator in other Arctic areas (Finley et al. 1990).
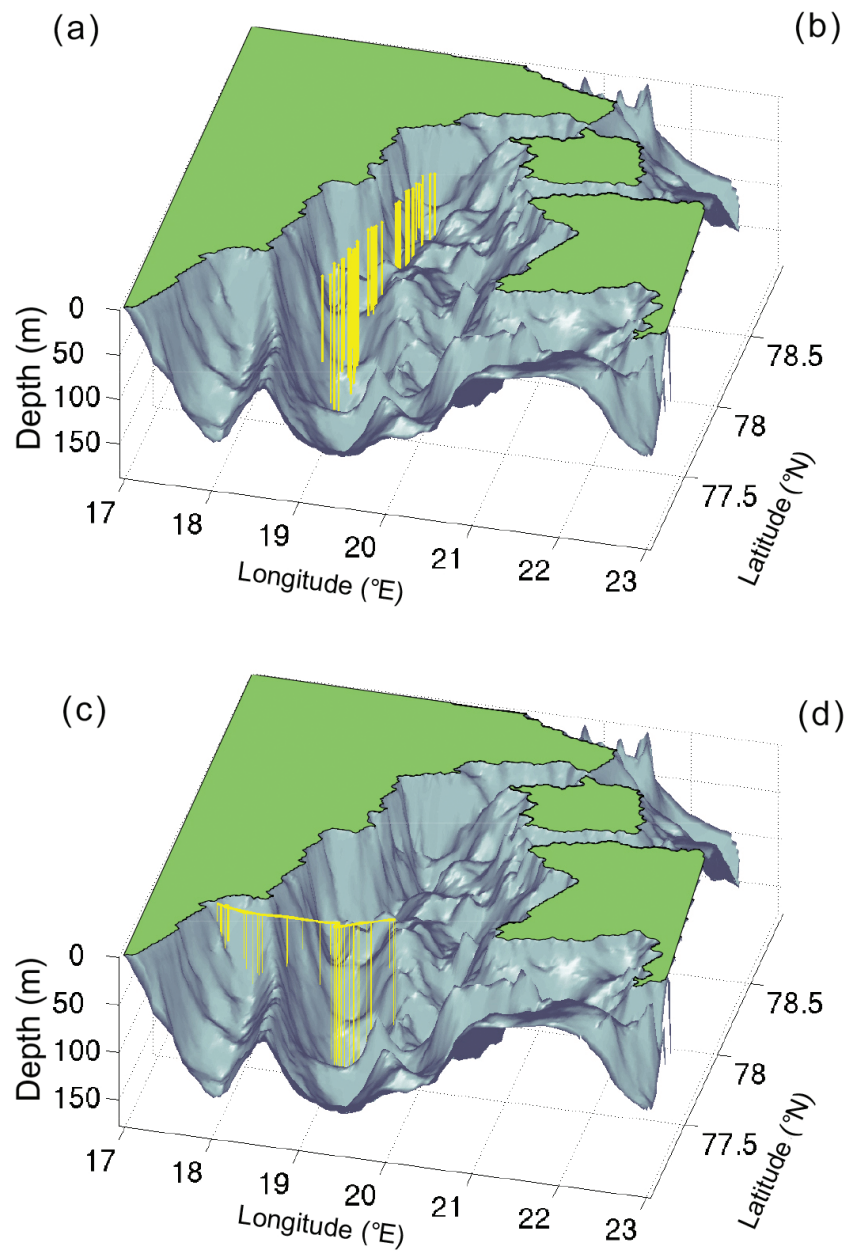

The second tracking study of white whales in Svalbard, conducted in 2001, included testing of a prototype for a satellite-linked CTD logger (Lydersen et al. 2002). White whales were chosen as the subject for this work because they are small enough to be captured and handled, yet big enough to carry the first-generation of CTD loggers without undue stress. Fieldwork was conducted late in the year (November), in hopes that the tags would still function when sea ice formed and the whales moved offshore into deeper waters. The prototype tags worked and the 540 CTD profiles that were successfully transmitted revealed new information about the hydrographic conditions in the study area during early winter (Fig. 3), including the presence of a bathymetrically steered warm-water mass that circulated within Storfjorden. Perhaps more
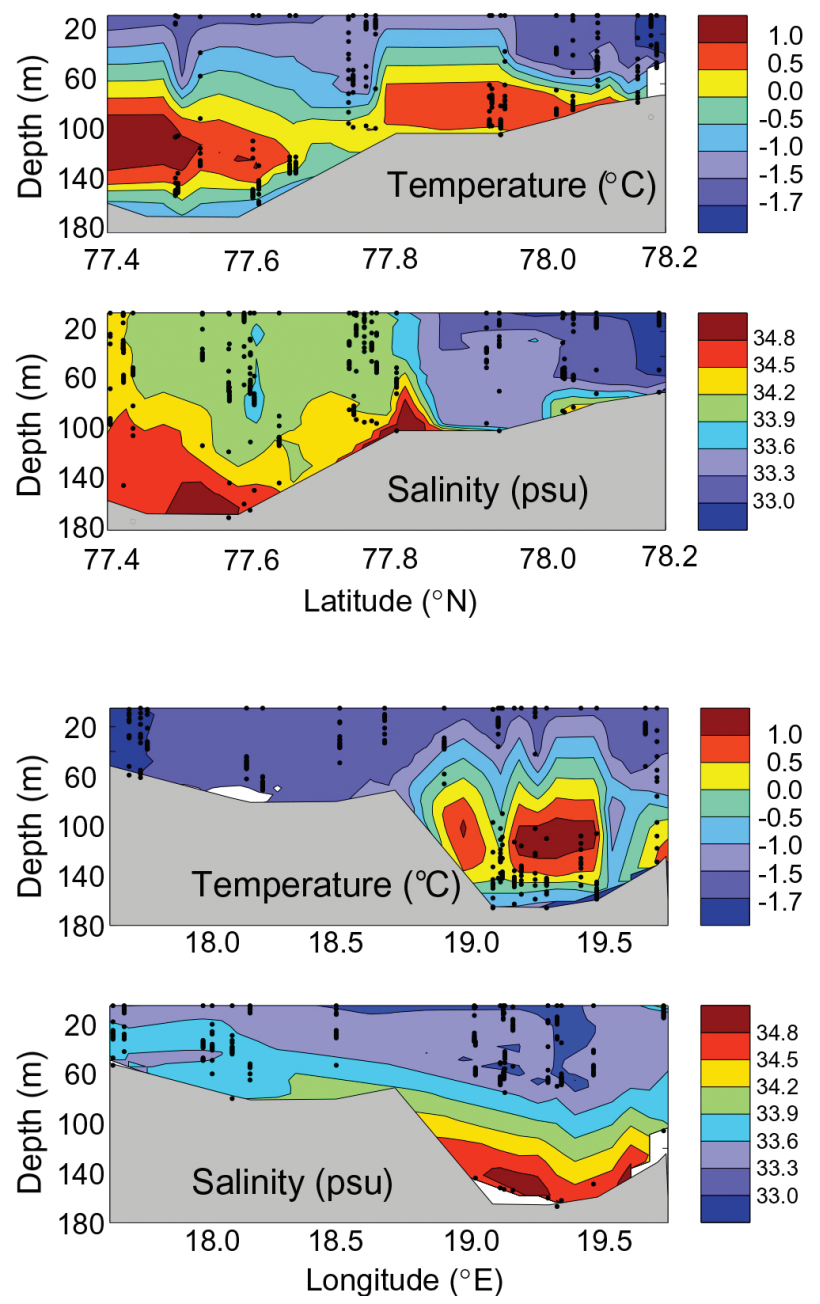

Fig. 3 CTD transects in Storfjorden, Svalbard. The maps show the locations of selected dives performed by a white whale (each yellow spike represents a dive; the length of the spikes represents dive depth) carrying a CTD tag, along (a) a north-south transect and (c) an east-west transect superimposed on a three-dimensional bathymetric map of Storfjorden, Svalbard. CTD casts produced during these dives are the basis for the temperature and salinity profiles shown in (b) and (d), respectively. Each dot in (b) and (d) represents a location where a CTD measurement was taken. (Figure from Lydersen et al. 2002.) 
importantly, this study demonstrated the feasible of using marine mammals to collect oceanographic data in a cost-effective manner to study the habitat of the animals in situ, as well as providing data for physical oceanography studies. The use of advanced generations of these tags has been revolutionary in terms of data collection, particularly from remote, hard to access, ice-covered areas in polar regions (see, for example, www.meop.net). These tags also documented that white whales occupied areas that had sea-ice concentrations up to $90 \%$ and that the whales routinely dove to the bottom to forage under extensive drift ice during late fall and winter.

The third tracking study was conducted in 2013-16, with the primary purpose of investigating whether the distribution or behaviour of white whales had been altered by the rapid changes in environmental conditions that took place in the early 2000s as a result of global warming (Vacquie-Garcia et al. 2018). Environmental conditions, especially on the west coast of Svalbard, changed precipitously in 2006, when large influxes of warm Atlantic Water prevented shore-fast sea ice from forming. Although sea ice does cover some small sill fjords and, in some years, open fjord areas, the sea-ice extent and thickness has not returned to pre-2006 levels. In addition to the declines in the available sea ice, the glacier fronts that the whales used for foraging are shrinking as higher air and water temperatures are causing negative mass balance, inducing melt and retraction of tidewater glaciers up onto shore (see Lydersen et al. 2014 for details). The tracking study showed that glacier fronts were still important areas for white whales in Svalbard, but that they spent significantly less time in this habitat than previously (Vacquie-Garcia et al. 2018). During the recent tracking period, the whales spent more time out in the fjords, sometimes kilometres away from the coastline. This was especially pronounced on the west side of Svalbard and suggests that the whales have likely diversified their foraging patterns to include prey in the Atlantic Water masses that now prevail in these fjords (Hamilton et al. 2019). It appears that the white whales are coping with current changes in the environment by displaying some behavioural plasticity, unlike another Arctic marine mammal in this area, the ringed seal (Pusa hispida), which has retracted into small home ranges very close to glacier fronts and has not shifted to the new potential prey available in the Atlantic Water (Hamilton et al. 2019; Bengtsson et al. 2020). This tracking study also showed that there was a seasonal pattern (both in the new and old data set) to the whales' distribution: the white whales spent the majority of their time in summer on the west coast of Svalbard and moved to the east coast during winter, occupying drift-ice areas, sometimes with ice concentrations of 80-100\% (Vacquie-Garcia et al. 2018).
The tracking data from these white whales have also been used for methodological studies. Used in combination with tracking data from several other species, a new algorithm based on swimming speed, distance between successive Argos locations and turning angles was developed to filter tracks. This new speed-distance-angle filter preserved a significantly higher percentage of good-quality Argos positions compared to other filters that used only estimated speed of travel to cull potentially erroneous location points (Freitas, Lydersen et al. 2008). Another study presented a novel method for quantifying habitat selection and predicting habitat use for white whales, as well as and ringed seals (Freitas, Kovacs et al. 2008). Habitat use intensities are explored using first-passage time, and these data were then used in Cox Proportional Hazard models to quantify habitat selection. This new combination of analyses permitted evaluation of which habitat characteristics best explained the risk (or 'hazard') of the animal leaving an area of a given radius (i.e., what features of the habitat were preferred). In addition, these models can be used to construct spatial predictions, such as maps of population-level space use that can be useful in the design of protected areas (Freitas, Kovacs et al. 2008).

\section{Diving}

Analyses of 55000 dives collected from the tracking records of adult males (2013-16) showed that Svalbard white whales rarely dive to great depth, which is not surprising given their close association with the coast (Vacquie-Garcia et al. 2019). Average dive depth was only $13 \pm 26 \mathrm{~m}$ (max recorded depth $=350 \mathrm{~m}$ ), and dive durations were very short (average $97 \pm 123 \mathrm{~s}$, max $31.4 \mathrm{~min}$; Vacquie-Garcia et al. 2019). No diel patterns were found; however, dive behaviour did vary with the habitat the whales occupied. When the animals were in front of glaciers, they optimized the time spent at the bottom of their dives, and dives were followed by longer periods of resting at the surface, in accordance with what would be expected when foraging. This type of dive behaviour was also documented during some of the time that the animals spent out in the fjords away from the coastline, providing further support that the white whales in Svalbard probably do some of their foraging within the fjords in recent years. Similar to the earlier tagging period, transits between fjords followed the coastline, and dives during transits were shallow, with the whales swimming just below the surface much of the time. Finally, when sea ice forms along the coast in the autumn/winter, the whales are forced to leave the shore and move into areas with deeper waters and drifting ice. In this habitat, they dive deeper, down to the seabed, and they minimize their time at the surface. The limited surface time might be in part to avoid surface 
predation by polar bears in dense sea-ice areas (VacquieGarcia et al. 2019). The dive data have also been used to calculate surface-availability correction factors for white whale aerial surveys (Vacquie-Garcia et al. 2020).

\section{Diet}

Since there is no harvest of white whales in Svalbard, indirect approaches have been used to study their diet. The fatty-acid composition of the blubber from live-captured adult male white whales off the west coast of Svalbard was analysed and compared by Dahl et al. (2000), with the fatty acid composition of various potential prey species. Complete-column blubber biopsies from the whales and whole-body compositions of 12 potential prey species were homogenized (separately), and their fatty acids were extracted and analysed. The blubber of the whales consisted almost entirely of triacylglycerols. Sixteen of the 22 fatty acids that were consistently found in the blubber of the whales were also found in most of the potential prey species. A principal component analysis run on these 16 fatty acids suggested that the most common prey was polar cod, followed by capelin (Mallotus villotus) and some invertebrates, including the shrimp Pandalus borealis (Dahl et al. 2000).

The staple diet of calves is milk, and on several occasions, females with young calves have been captured during the net captures in Svalbard. In 1998, three mother-calf pairs were captured, and milk was collected from all three mothers. Two of the mothers were grey (young animals), while the third mother was pure white (likely $>20$ years of age). Two of the calves still had their umbilical cords attached; they were 142 and $143 \mathrm{~cm}$ long, respectively. The third calf was older and was 205 $\mathrm{cm}$ long (with no remaining umbilical cord). All the milk samples had a greenish colour, and chemical analyses of the milk composition showed fat contents of $30.7 \%, 33.2 \%$ and $43.7 \%$ and protein contents of $8.10 \%, 8.69 \%$ and $7.26 \%$ for the shortest, medium and longest calf, respectively (Lydersen \& Kovacs, unpubl. data). The fat content of the milk seems to increase during the lactation period, similar to what is shown in most seal species (Lydersen \& Kovacs 1999). This is thought to be a means of maintaining water balance (i.e., decrease water content in the milk) in the mother as lactation progresses; the calf is also likely more capable of digesting and mobilizing the fat in the milk as it grows older as well. Typical of marine mammals, the white whale milk contained very few carbohydrates (Urashima et al. 2002). Chemical composition of the oligosaccharides in white whale milk from Svalbard showed that the milk had no free lactose, suggesting that this normally common carbohydrate is not an important source of energy for these whales (Urashima et al. 2002).

Another study involving milk analysed the fatty acid composition in the milk, as well as in the blubber of calves and their mothers in parallel (Birkeland et al. 2005). Four mother-calf pairs were included in this study: the three pairs mentioned earlier in addition to another pair in which the calf was $255 \mathrm{~cm}$ long. Based on data on body lengths versus age from west Greenland (Heide-Jørgensen \& Teilmann 1994), two of the calves were estimated to be less than one week old, one was two months old and the largest calf was approximately one year old (Birkeland et al. 2005). The youngest calves had fatty-acid compositions that were significantly different from the fatty-acid composition of either the milk or the blubber of their mothers (Fig. 4). The fatty-acid composition in the milk was also significantly different from the fatty-acid composition of the adult whales studied previously. The fatty-acid composition of the blubber of the calves changed gradually with age and became more similar to that of their mothers, rather than the fatty acid composition of the milk (i.e., their diet). The oldest calf had a fatty-acid composition similar to that of adult whales (Birkeland et al. 2005). These ontogenetic changes during growth occur semi-autonomously of the diet. Although all nutrients obviously come from the milk ingested, the relative composition of the fatty acids changed in terms of uptake and deposition into the blubber of the youngsters. Anatomical or physiological adjustments crucial to survival in the cold marine environment likely have a strong role in governing how and where various fatty acids are deposited in the early life of calves. This selective processing of fatty acids is likely quite different during ontogeny compared with fat deposition later in life.

\section{Distribution and abundance}

White whales are commonly observed around the archipelago during the seasonal period with daylight (MarchNovember). They often occur near settlements on the west coast of Svalbard, including the Ny-Ålesund Research Station in Kongsfjorden (Hop et al. 2002), in Adventfjorden (close to Longyearbyen) and near the Russian settlement in Barentsburg, located in Grønfjorden (Norwegian Polar Institute Marine Mammal Sightings Database, www.npolar.nolen $\backslash$ services $\backslash \mathrm{mms})$. Based on 286 observations of groups comprising 5700 individuals (during the period 2002-2014), white whales were found to occupy a unique, narrow, shallow-water, coastal niche in the cetacean community of the archipelago (Storrie et al. 2018). Many of the observations reported in Storrie et al. (2018) were in areas with considerable ice cover (>30\% ice cover), although observations were also 


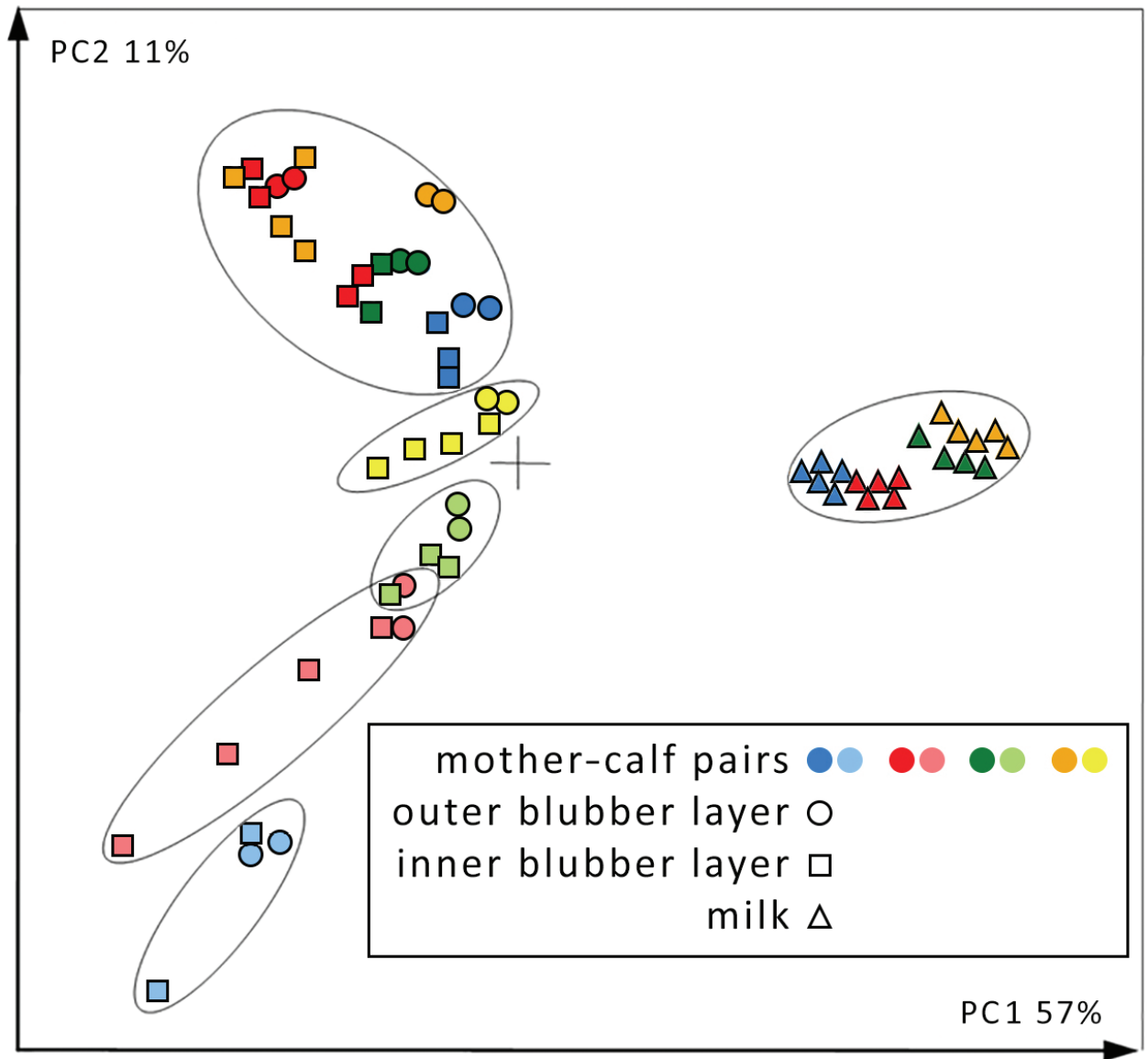

Fig. 4 Biplot of the fatty-acid composition in blubber samples from white whale mothers and calves and in milk samples. The calf in the mother-calf pair represented in blue was the youngest, followed by red, green and yellow (the oldest calf). (Figure modified from Birkeland et al. 2005.)

recorded in ice-free waters. Sea surface temperatures where white whales were observed were colder than where the migrant cetaceans (e.g., fin [Balaenoptera physalus], blue [B. musculus], humpback [Megaptera novaeangliae] and minke [Balaenoptera acutorostrata] whales) were found, with about $25 \%$ of the observations occurring in areas with sea-surface temperatures below $2{ }^{\circ} \mathrm{C}$ (Storrie et al. 2018). No white whales were observed in offshore areas during an aerial survey of ice-associated whales, covering a $53000 \mathrm{~km}^{2}$ area along the marginal ice zone, during summer 2015 (Vacquie-Garcia et al. 2017). Observations reported to the sighting database during the period of the offshore survey included normal sighting levels for white whales along the coast (Vacquie-Garcia et al. 2017).

When summing up the world population size for white whales in the Handbook of marine mammals (Brody 1989), it is stated that Lønø \& Øynes (1961) found a previous estimate of 10 000-12 000 animals excessive for the Svalbard population. This is a slightly erroneous citation of Lønø \& Øynes (1961), who actually refer to a statement from a white whale hunter who suggested that a large white whale group that he came across consisted of 10 000-12 000 animals. Lønø \& Øynes (1961) did indeed question this number, although it has been repeatedly cited in popular literature as though it was the result of an abundance survey. In fact, the population size of white whales in Svalbard was simply unknown until the first survey of the population in 2018 (Vacquie-Garcia et al. 2020). Data from the tracking studies described earlier were crucial when creating the survey design, which included three strata to account for the unusual distribution pattern of this population. Because of their tightly coastal distribution, the entire coastline of all of the major islands in the archipelago was surveyed. In addition, based on the recent change in the behaviour described earlier, the fjords on the west coast of Svalbard were surveyed using a distance sampling line transect design. In addition, in order to account for whales that were potentially not following the documented behavioural patterns, transect lines perpendicular to the coastline were flown from the 
coastline stratum out into offshore areas. These transects were composed of two parallel lines (one outbound and one inbound) extending out to $12 \mathrm{~km}$, flown $90 \mathrm{~km}$ apart throughout the whole of Svalbard (Fig. 5). In total, $4965 \mathrm{~km}$ of coastline, $1481 \mathrm{~km}$ of fjord transects and 535 $\mathrm{km}$ of offshore transects were flown. Groups of white whales were observed on 22 occasions, all within the coastline stratum (Vacquie-Garcia et al. 2020). After correcting for surface availability based on the diving study described earlier, the Svalbard population of white whales was estimated to consist of 549 (CI: 436-723) animals (Vacquie-Garcia et al. 2020). This makes the Svalbard population one of the smallest white whale populations in the world, which is of concern given ongoing climate change and other threats to these animals that could limit the recovery of this population.

\section{Genetics}

In a recent global review of narwhals (Monodon monoceros) and white whales, 21 extant white whale stock were recognized (Hobbs et al. 2019). In this assessment, Svalbard is delineated as an independent stock, while another stock to the east—called the Barents-Kara-Laptev seas stock-includes animals in the waters of the Russian archipelago of Franz Josef Land. However, there are no genetic studies that compare material from the Svalbard stock to animals in Franz Josef Land or the Kara or Laptev

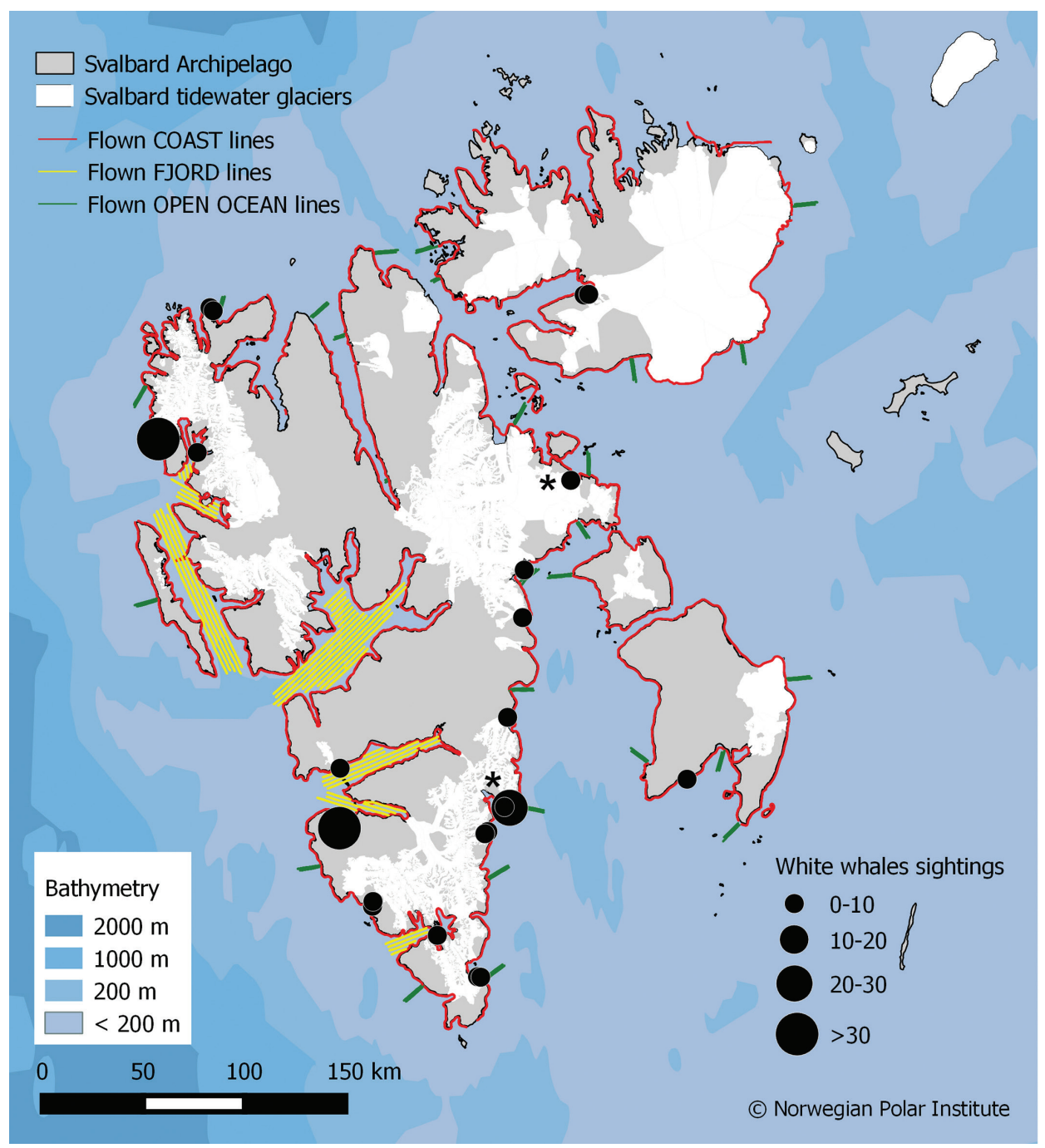

Fig. 5 Locations of white whale sightings during an aerial survey of Svalbard, Norway, summer 2018. Asterisks represent mother-calf pair sightings. Red lines represent coastlines surveyed, yellow lines the transects flown in the fjords on the west coast of Svalbard and green lines show offshore transect lines flown from shore to offshore areas perpendicular to the coastline. (Figure from Vacquie-Garcia et al. 2020.) 
seas, so this stock delineation is somewhat uncertain. Animals in the White Sea in Russia and in west Greenland have been investigated in relation to Svalbard animals, and all three of these show genetic differences from each other (O'Corry-Crowe et al. 2010).

From the early tracking studies in Svalbard, it was apparent that the whales caught and tagged in the southern parts of the archipelago did not move into the northern parts of the archipelago. Because white whales are certainly present in the north, this raised the question as to whether there were genetic subgroups among the white whales in this area. Therefore, the population structure was studied using various molecular markers to compare allele frequencies and haplotypes between white whales in the north (Krossfjorden) and in the south (Storfjorden; Fløystad 2012). Analyses indicated all of the animals in Svalbard waters belong to a single population.

Svalbard white whales have also been included in a comprehensive study of group structure and kinship in white whale societies (O'Corry-Crowe et al. 2020). White whales are highly social animals that live in groups. The average group size in Svalbard is 10, although groups up to 220 have been recorded (Storrie et al. 2018; Norwegian Polar Institute Marine Mammal Sighting Database). It has been suggested that white whale groups might be families connected through related females (Palsbøll et al. 2002), similar to killer whales and sperm whales (Physeter macrocephalus). However, MtDNA-microsatellite profiling combined with relatedness and network analyses suggested a more complex nature to social groupings of white whales when viewed across their circumpolar range (O'CorryCrowe et al. 2020). This species appears to have a much more complex arrangement of extended relationships between family members and other individuals, with seasonal sex segregation being a common feature in Svalbard and elsewhere. Pod structure is quite dynamic and groups do sometimes, but not always, comprise related individuals. When relatedness is high, it is often through paternal linkages. The long-life span of white whales and the extended community they live in probably facilitate the exchange of knowledge among generations and may allow for the animals to benefit from long-term mutual co-operation. Harvesting older animals, particularly in small populations, risks the loss of essential ecological knowledge within the group (O'Corry-Crowe et al. 2020).

Genetic studies should be conducted to determine whether the white whales in Svalbard and in Franz Josef Land are independent populations or if the animals in these two archipelagos are one common population. The ice edge linking Svalbard and Franz Josef Land-and therefore, the likeliest white whale travel route between the two archipelagos-is shortest and most clearly defined during the winter, when it furthest south, but it is not known whether exchange between these populations takes place now or has taken place in the past. Currently, contact seems improbable, but heavier ice conditions in the past and larger population size might have facilitated more regular exchange, although natal fidelity might have always kept the whales in these two areas genetically separated (O'Corry Crowe et al. 2018).

\section{Acoustics}

White whales are considered one of the most vociferous cetacean species and are often referred to as the canaries of the sea. However, Svalbard's white whales are remarkably quiet (Karlsen et al. 2002). This population does produce most of the vocalizations that have been documented in other populations, as well as some minor vocal novelties, but groups are quiet most of the time (Karlsen et al. 2002). This relative silence could be due to the type of groups encountered (e.g., all-male) during the study but is more likely an anti-predator strategy in response to killer whales. Lack of vocal signalling, in combination with their extremely tight coastal movement pattern (described earlier), suggests that predation is (or at least has been) an important factor shaping the behaviour of the Svalbard white whales.

Passive acoustic data loggers were used in a remote survey of white whales that included whales in Kongsfjorden, a site in Alaska and a site in the White Sea, Russia (Castellote et al. 2013). A combination of captive and open-water surveys in these three sites was used to document detection performance and to explore the use of logger angle and inter-click interval data to look at activity patterns and tidal influences on space use. One issue here, which is very relevant for Svalbard, is that long periods of silence may result in the loggers underestimating the presence of this species in an area.

Van Parijs et al. (2003) analysed recordings of vocalization during capturing events of white whales in Svalbard. Only half of the animals (four out of eight) produced sounds during these events. One sub-adult female produced repetitive broadband clicks, while a solitary calf produced harmonic sounds, which were interpreted as being mother-calf 'contact calls.' In addition, the mother in a mother-calf pair produced 'crooning' broadband clicks while moving her head toward her calf. Her calf produced three types of frequency-modulated sounds, interspersed within broadband click trains. Even if the sounds produced by these individuals during handing were highly variable, they all likely represented various 'contact calls.' No sounds were heard from any of the animals during their period of restraint or upon their release or during other recording sessions when animals were seen passing the capture net (Van Parijs et al. 2003). 


\section{Environmental pollution}

All odontocete whales have a poor capacity to metabolize POPs, which might play a role in the high concentrations of various POPs documented in Svalbard and elsewhere in white whales (Andersen et al. 2001; Wolkers et al. 2004; Andersen, Foreid et al. 2006; Wolkers et al. 2006; Villanger et al. 2011; Hoguet et al. 2013; Villanger et al. 2020). For many compounds, white whales have higher concentrations than polar bears even if the whales feed at lower trophic levels. For instance, $\Sigma D D T$ is five times higher in white whales in Svalbard compared to polar bears in the same area (Andersen et al. 2001) and some toxaphenes congeners are more than 200 times higher (Andersen, Foreid et al. 2006), though these two studies might be biased towards high levels because they were based on only adult males. In a study of accumulation of flame retardants (polybrominated diphenyl ethers) in the food chain in Svalbard, 13 different congeners were detected in white whales (of both sexes), while only one was detected in polar bears (Wolkers et al. 2004). This is because polar bears have the capacity to metabolize almost all of these flame retardants, which make that species unsuitable as an indicator of these compounds in the environment. White whales, on the other hand, are very suitable for such monitoring. Some of the levels of various POPS in white whales are a concern because they are found at levels high enough to induce disruptive effects on the whales' endocrine system, potentially causing negative effects on development, behaviour, fertility and survival. In a study in which levels of 56 organohalogen contaminants were measured together with circulating levels of thyroid hormones and thyroid stimulating hormones in white whales of both sexes (in various age groups) in Svalbard, negative influences of specific contaminants on the levels of thyroid hormones in the whales were found, with unknown effects on the health of the individuals or the population (Villanger et al. 2011).

A study of concentrations of perfluoroalkyl substances in white whales from 1996 to 2001 was compared with levels in white whales collected 15 years later, in 2013-14 (Villanger et al. 2020); samples in both periods included a mix of both sexes and a variety of age groups. In contrast to the substances mentioned earlier, which accumulate predominantly in lipid-rich tissues, perfluoroalkyl substances are mainly found in protein-rich tissues. The dominant perfluoroalkyl substance in white whales in Svalbard (perfluorooctane sulfonate) declined by $44 \%$ from the earlier to the later period, mainly as a result of a production phase-out and eventually global restriction on these compounds. Some other substances (perfluoroalkyl carboxylates) increased during the same period, which calls for continued vigilance and regular monitoring, as well as studies of biological effects of these and other contaminants (Villanger et al. 2020).

Halogenated dimethyl bipyrrols are naturally produced organohalogens that are globally distributed in the marine environment. Their levels were quantified by Tittlemier et al. (2002) in a number of marine mammals, including white whales in Svalbard. The geographical distribution of these compounds does not resemble that of anthropogenic organohalogens and suggests that transport (both atmospheric and by ocean currents) of these substances is from a source in the Pacific Ocean. Halogenated dimethyl bipyrrols contribute significantly to an organism's total organohalogen burden and likely have a long lifetime in the marine environment (Tittlemier et al. 2002).

Andersen, Gwynn et al. (2006) studied the specific activity of the anthropogenic radionuclide ${ }^{137} \mathrm{Cs}$ in muscle tissue from various marine mammals in Svalbard, including white whales. The concentration found was low $(0.67$ $\mathrm{Bq} / \mathrm{kg}$ w.w.), which is consistent with previously reported results showing low specific activities of this radionuclide in the Barents-Greenland Sea region during the last 20 years.

\section{Health and diseases}

Serum chemistry was assessed from 21 live-captured white whales in Svalbard, including calves, sub-adults and adults of both sexes, by Tryland et al. (2006). Concentrations of a suite of enzymes, metabolites and minerals were measured from what was assumed to be healthy animals to create a baseline for future health assessments. With some few exceptions, the measured concentrations of the various substances were strikingly similar to values reported from a white whale population in the Canadian Arctic.

Another study related to assessing health in Svalbard's white whales measured total serum concentrations of 11 thyroid hormones and associated metabolites using a newly developed liquid chromatography tandem mass spectrometry method (Hansen et al. 2017). In addition, thyroid hormone levels in plasma and serum were compared, since many researchers consider serum to be the optimal matrix for such analysis, while plasma is the matrix most often sampled in the field. The analyses showed the same results for both serum and plasma (Hansen et al. 2017).

In a study of the prevalence of the parasite Toxoplasma gondii in Svalbard, where plasma from many marine mammal species was analysed, antibodies were found in polar bears, ringed and bearded seals (Erignathus barbatus) but not in white whales (Jensen et al. 2010). 


\section{Other potential anthropogenic impacts}

Data for Svalbard's white whales were also part of a circumpolar study where the distribution of all Arctic endemic cetaceans was compared to shipping routes and areas with various forms of hydrocarbon development with the aim of highlighting areas of special concern for conservation (Reeves et al. 2014). Measures suggested in this study to reduce impacts of human activities included: careful planning of ship traffic lanes and ship speed restrictions; temporal or spatial closures of areas where critical processes for whales such as calving, calf rearing, resting or intense feeding take place; strict regulation of seismic surveys and other sources of loud underwater noise and close and sustained monitoring of whale populations in order to track their responses to environmental disturbance (Reeves et al. 2014).

\section{Climate change}

The Arctic is warming faster than any place on Earth, and the Barents Sea has experienced the greatest reduction in sea ice in the Arctic, with the period when sea ice is present lessening by more than 20 weeks from 1979 to 2013 (Laidre et al. 2015). This will obviously have impacts on ice-associated marine mammals in this area, including white whales, if they are not able to respond rapidly to the ongoing changes in their habitats (Learmonth et al. 2006; Kovacs \& Lydersen 2008; Kovacs et al. 2011; Laidre et al. 2015; Descamps et al. 2017). Sea ice provides shelter during storms that is likely important to young animals. In addition, it provides protection from open-water predators such as killer whales. Killer whales are a serious threat to white whales in areas where there is little sea ice. Changing food webs is likely to impact food availability; the white whale's primary prey species in Svalbard, polar cod (Dahl et al. 2000), is already declining in the Barents Sea region, concomitant with reductions in sea ice. Additionally, melting and retraction of glaciers is shrinking key feeding areas in front of tidewater glaciers, though white whales seem to be showing some plasticity and may already be feeding on Atlantic prey species given that they seem to be spending some time out in the fjords in recent years (Hamilton et al. 2019). Intensified impacts of contaminants in a warming Arctic are also a concern given the already high levels of toxins in Svalbard white whales (see earlier; Andersen et al. 2001; Wolkers et al. 2004; Andersen, Foreid et al. 2006; Wolkers et al. 2006; Villanger et al. 2011) and the evidence of impacts on other more southerly populations in the past (see Lebeuf et al. 2014). Heightened disease risks are yet another threat as new species shift their distributions northward and introduced diseases may survive in a warmer Arctic marine environment, which was previously inhospitable (VanWormer et al. 2019). Another unknown is potential negative impacts from increased underwater noise from ship traffic and industrial activities such as seismic exploration on the distribution, health and welfare of the white whales in Svalbard (Reeves et al. 2014; Norman et al. 2015). The small size of this population is in itself a concern (see Hobbs et al. 2015), particularly in a changing environment, because small populations tend to have lower resilience.

\section{Acknowledgements}

The authors thank all the colleagues who have contributed to Norwegian Polar Institute's white whale research programme over the years in all aspects of the work, from planning and conducting fieldwork through laboratory work, data analyses and manuscript writing. Olof Bengtsson constructed Fig. 2 and ensured that the manuscript was submitted to the journal by the deadline set for the special cluster, while the authors were in the field and offline.

\section{Disclosure statement}

The authors report no conflict of interest.

\section{Funding}

This study was supported financially by the Norwegian Polar Institute, the Norwegian Research Council (through the projects ICE whales [244488/E10], Tidewater Glacier Retreat Impact on Fjord Circulation and Ecosystems and Glaciers as Arctic Ecosystem Refugia), the Norwegian Polar Institute's Centre for Ice, Climate and Ecosystems and the Fram Centre's Fjord and Coast Flagship programme. This review was presented at the Second International Workshop on Beluga Whale Research and Conservation, 12-14 March 2019, Mystic Aquarium, Mystic, CT, USA. This special issue on white whales in Polar Research was funded by the Ministry of Climate and Environment (Norway) on behalf of Conservation of Arctic Flora and Fauna (CAFF).

\section{References}

Andersen G., Foreid S., Skaare J.U., Jenssen B.M., Lydersen C. \& Kovacs K.M. 2006. Levels of toxaphene congeners in white whales (Delphinapterus leucas) from Svalbard, Norway. Science of the Total Environment 357, 128-137, doi: 0.1016/j.scitotenv.2005.05.014.

Andersen G., Kovacs K.M., Lydersen C., Skaare J.U., Gjertz I. \& Jenssen B.M. 2001. Concentrations and patterns of organochlorine contaminants in white whales 
(Delphinapterus leucas) from Svalbard, Norway. Science of the Total Environment 264, 267-281, doi: 10.1016/ S0048-9697(00)00765-8.

Andersen M., Gwynn J.P., Dowdall M., Kovacs K.M. \& Lydersen C. 2006. Radiocaesium $\left({ }^{137} \mathrm{Cs}\right)$ in marine mammals from Svalbard, the Barents Sea and the north Greenland Sea. Science of the Total Environment 363, 87-94, doi: 10.1016/j.scitotenv.2005.06.019.

Bengtsson O., Lydersen C., Kovacs K.M. \& Lindström U. 2020. Ringed seal (Pusa hispida) diet on the west coast of Spitsbergen, Svalbard, Norway. Polar Biology 43, 773-788, doi: 10.1007/s00300-020-02684-5.

Birkeland A., Kovacs K.M., Lydersen C. \& Grahl-Nielsen O. 2005. Transfer of fatty acids from mothers to their calves during lactation in white whales (Delphinapterus leucas). Marine Ecology Progress Series 298, 287-294, doi: 10.3354/ meps298287.

Brody P.F. 1989. The white whale Delphinapterus leucas (Palls, 1779). In S.H. Ridgway \& R. Harrison (eds.): Handbook of marine mammals. Vol. 4. River dolphins and the larger toothed whales. Pp. 119-144. London: Academic Press.

Castellote M., Leeney R.H., O'Corry-Crowe G., Lauhakangas R., Kovacs K.M., Lucey W., Krasnova V., Lydersen C., Stafford K.M. \& Belikov R. 2013. Monitoring white whales (Delphinapterus leucas) with echolocation loggers. Polar Biology 36, 493-509, doi: 10.1007/s00300-012-1276-2.

Dahl T.M., Lydersen C., Kovacs K.M., Falk-Petersen S., Sargent J., Gjertz I. \& Gulliksen B. 2000. Fatty acid composition of the blubber in white whales (Delphinapterus leucas). Polar Biology 23, 401-409, doi: 10.1007/s003000050461.

Descamps S., Aars J., Fuglei E., Kovacs K.M., Lydersen C., Pavlova O., Pedersen A.Ø., Ravolainen V. \& Strøm H. 2017. Climate change impacts on wildlife in a High Arctic archipelago-Svalbard, Norway. Global Change Biology 23, 490-502, doi: 10.1111/gcb.13381.

Finley K.J., Miller G.W., Davis R.A. \& Green C.R. 1990. Reactions of belugas, Delphinapterus leucas, and narwhals, Monodon monoceros, to ice-breaking ships in the Canadian High Arctic. Canadian Bulletin of Fisheries and Aquatic Sciences 224, 97-117.

Fløystad I.M.B. 2012. An analysis of the population structure of white whales (Delphinapterus leucas) in Svalbard. MSc thesis, University of Oslo.

Freitas C, Kovacs K.M., Lydersen C. \& Ims R.A. 2008. A novel method for quantifying habitat selection and predicting habitat use. Journal of Applied Ecology 45, 1213-1220, doi: 10.1111/j.1365-2664.2008.01505.x.

Freitas C., Lydersen C., Fedak M.A. \& Kovacs K.M. 2008. A simple new algorithm to filter marine mammal Argos locations. Marine Mammal Science 24, 315-325, doi: 10.1111/j.1748-7692.2007.00180.x.

Gjertz I. \& Wiig Ø. 1994. Distribution and catch of white whales (Delphinapterus leucas) at Svalbard. Meddelelser om Gronland, Bioscience 39, 93-97.

Hamilton C.D., Vacquié-Garcia J., Kovacs K.M., Ims R.A. \& Lydersen C. 2019. Contrasting changes in space use induced by climate change in two Arctic marine mammal species. Biology Letters 15, article no. 20180834, doi: 10.1098/rsbl.2018.0834.
Hansen M., Villanger G.D., Bechshøft T., Levin M., Routti H., Kovacs K.M. \& Lydersen C. 2017. Circulating thyroid hormones and associated metabolites in white whales (Delphinapterus leucas) determined using isotope-dilution mass spectrometry. Environmental Research 156, 128-131, doi: 10.1016/j.envres.2017.03.027.

Heide-Jørgensen M.P. \& Teilmann J. 1994. Growth, reproduction, age structure and feeding habits of white whales (Delphinapterus leucas) in west Greenland waters. Meddelelser om Grønland, Bioscience 39, 195-2 12.

Hobbs R.C., Reeves R.R., Prewitt J.S., Desportes G., BretonHoneyman K., Christensen T., Citta J.J., Ferguson S.H., Frost K.J., Garde E., Gavrilo M., Ghazal M., Glazov D.M., Gosselin J.-F., Hammill M., Hansen R.G., Harwood L., Heide-Jørgensen M.P., Inglangasuk G., Kovacs K.M., Krasnova V.V., Kuznetsova D.M., Lee D.S., Lesage V., Litovka D.I., Lorenzen E.D., Lowry L.F., Lydersen C., Matthews C.J.D., Meschersky I.G., Mosnier A., O'CorryCrowe G., Postma L., Quakenbush L.T., Shpak O.V., Skovrind M., Suydam R.S. \& Watt C.A. 2019. Global review of the conservation status of monodontid stocks. Marine Fisheries Review 81(3-4), 1-53.

Hobbs R.C., Wade P.R. \& Shelden K.E.W. 2015. Viability of a small, geographically-isolated population of beluga whales: the effects of hunting, predation, and catastrophes in Cook Inlet, Alaska. Marine Fisheries Review 77, 59-88, doi: 10.7755/MFR.77.2.4.

Hoguet J., Keller J.M., Reiner J.L., Kucklick J.R., Bryan C.E., Moors A.J., Pugh R.S. \& Becker P.R. 2013. Spatial and temporal trends of persistent organic pollutants and mercury in beluga whales (Delphinapterus leucas) from Alaska. Science of the Total Environment 449, 285-294, doi: 10.1016/j.scitotenv.2013.01.072.

Hop H., Pearson T., Hegseth E.N., Kovacs K.M., Wiencke C., Kwasniewski S., Eiane K., Mehlum F., Gulliksen B., Wlodarska-Kowalczuk M., Lydersen C., Weslawski J.M., Cochrane S., Gabrielsen G.W., Leakey R., Lønne O.J., Zajaczkowski M., Falk-Petersen S., Kendall M., Wängberg S.-Å., Bischof K., Voronkov A.Y., Kovaltchouk N.A., Wiktor J., Poltermann M., di Prisco G., Papucci C. \& Gerland S. 2002. The marine ecosystem of Kongsfjorden, Svalbard. Polar Research 21, 167-208, doi: $10.1111 / \mathrm{j} .1751$ 8369.2002.tb00073.x.

Isachsen G. 1921. Folk, fangst og færder, nordmændene paa Spitsbergen og Ishavet. (People, hunting and travels; Norwegians on Spitsbergen and the Arctic Ocean.) Det Norske Geografiske Selskabs Aarbok 28-30 (1916-1919), 121-250.

Jensen S.K., Aars J., Lydersen C., Kovacs K.M. \& Åsbakk K. 2010. The prevalence of Toxoplasma gondii in polar bears and their marine mammal prey: evidence for a marine transmission pathway? Polar Biology 33, 599-606, doi: 10.1007/s00300-009-0735-x.

Karlsen J., Bisther A., Lydersen C., Haug T. \& Kovacs K.M. 2002. Summer vocalisations of adult male white whales (Delphinapterus leucas) in Svalbard, Norway. Polar Biology 25, 808-817, doi: 10.1007/s00300-002-0415-6.

Kovacs K.M. \& Lydersen C. 2008. Climate change impacts on seals and whales in the North Atlantic Arctic and 
adjacent shelf waters. Science Progress 91, 117-150, doi: $10.3184 / 003685008 \times 324010$.

Kovacs K.M., Lydersen C., Overland J.E. \& Moore S.E. 2011. Impacts of changing sea-ice conditions on Arctic marine mammals. Marine Biodiversity 41, 181-194, doi: 10.1007/ s12526-010-0061-0.

Laidre K.L., Angliss R.P., Born E.W., Boveng P., Ferguson S., Kovacs K.M., Lowry L., Lydersen C., Moore S., Quakenbush L., Regehr E.V., Stern H., Ugarte F., Vongraven D. \& Wiig Ø. 2015. A circumpolar assessment of Arctic marine mammals, sea ice loss, and conservation challenges in the 21 st century. Conservation Biology 29, 724-737, doi: $10.1111 /$ cobi.12474.

Learmonth J.A., MacLeod C.D., Santos M.B., Pierce G.J., Crick H.Q.P. \& Robinson R.A. 2006. Potential effects of climate change on marine mammals. Oceanography and Marine Biology 44, 431-464, doi: 10.1201/9781420006391. ch8.

Lebeuf M., Measures L., Noel M., Raach M. \& Trottier S. 2014. A twenty-one-year temporal trend of persistent organic pollutants in St. Lawrence Estuary beluga, Canada. Science of the Total Environment 485, 377-386, doi: 10.1016/j.scitotenv.2014.03.097.

Lønø O. \& Øynes P. 1961. White whale fishery at Spitsbergen. Norsk Hvalfangst Tidende 50, 267-287.

Lydersen C., Assmy P., Falk-Petersen S., Kohler J., Kovacs K.M., Reigstad M., Steen H., Strom H., Sundfjord A., Varpe O., Walczowski W., Weslawski J.M. \& Zajaczkowski M. 2014. The importance of tidewater glaciers for marine mammals and seabirds in Svalbard, Norway. Journal of Marine Systems 129, 452-471, doi: 10.1016/j. jmarsys.2013.09.006

Lydersen C. \& Kovacs K.M. 1999. Behaviour and energetics of ice-breeding, North Atlantic phocid seals during the lactation period. Marine Ecology Progress Series 187, 265-281, doi: 10.3354/meps 187265 .

Lydersen C., Martin A.R., Kovacs K.M. \& Gjertz I. 2001. Summer and autumn movements of white whales Delphinapterus leucas in Svalbard, Norway. Marine Ecology Progress Series 219, 265-274, doi: 10.3354/meps219265.

Lydersen C., Nøst O.A., Lovell P., McConnell B.J., Gammelsrød T., Hunter C., Fedak M.A. \& Kovacs K.M. 2002. Salinity and temperature structure of a freezing Arctic fjord-monitored by white whales (Delphinapterus leucas). Geophysical Research Letters 29, article no. 2119 , doi: 10.1029/2002GL015462.

Norman S.A., Hobbs R.C., Goertz C.E., Burek-Huntington K.A., Shelden K.E.W., Smith W.A. \& Beckett L.A. 2015. Potential natural and anthropogenic impediments to the conservation and recovery of Cook Inlet beluga whales, Delphinapterus leucas. Marine Fisheries Review 77, 89-105, doi: 10.7755/MFR.77.2.5.

O'Corry-Crowe G.M., Lydersen C., Heide-Jørgensen M.-P., Hansen L., Mukhametov L.M., Dove O. \& Kovacs K.M. 2010. Population genetic structure and evolutionary history of North Atlantic beluga whales (Delphinapterus leucas) from west Greenland, Svalbard and the White Sea. Polar Biology 33, 1179-1 194, doi: 10.1007/s00300-010-0807-y.
O'Corry-Crowe G.M., Suydam R., Quakenbush L., Potgieter B., Harwood L., Litovka D., Ferrer T., Citta J., Burkanov V., Frost K. \& Mahoney B. 2018. Migratory culture, population structure and stock identity in North Pacific beluga whales (Delphinapterus leucas). PLoS One 13, e0194201, doi: 10.1371/journal.pone.0194201.

O'Corry-Crowe G.M., Suydam R., Quakenbush L., Smith T.G., Lydersen C., Kovacs K.M., Orr J., Harwood L., Litovka D. \& Ferrer T. 2020. Group structure and kinship in beluga whale societies. Scientific Report 10, article no. 11462, 1-21, doi: 10.1038/s41598-020-67314-W.

Palsbøll P.J., Heide-Jørgensen M.P. \& Bérubé M. 2002. Analysis of mitochondrial control region nucleotide sequences from Baffin Bay belugas (Delphinapterus leucas): detecting pods or subpopulations? NAMMCO Scientific Publications 4, 39-50, doi: 10.7557/3.2836.

Reeves R.R., Ewins P.J., Agbayani S., Heide-Jørgensen M.P., Kovacs K.M., Lydersen C., Suydam R., Elliot W., Polet G., van Dijk Y. \& Blijleven R. 2014. Distribution of endemic cetaceans in relation to hydrocarbon development and commercial shipping in a warming Arctic. Marine Policy 44, 375-389, doi: 10.1016/j.marpol.2013.10.005.

Storrie L., Lydersen C., Andersen M., Wynn R.B. \& Kovacs K.M. 2018. Determining the species assemblage and habitat use of cetaceans in the Svalbard Archipelago, based on recorded observations from 2002-2014. Polar Research 37, articleno. 1463065, doi: 10.1080/17518369.2018.1463065.

Tittlemier S., Borrell A., Duffe J., Duignan P.J., Fair P., Hall A., Hoekstra P., Kovacs K.M., Krahn M.M., Lebeuf M., Lydersen C., Muir D., O'Hara T., Olson M., Pranschke J., Ross P., Siebert U., Stern G., Tanabe S. \& Norstrom R. 2002. Global distribution of halogenated dimethyl bipyrroles in marine mammal blubber. Archives of Environmental Contamination and Toxicology 43, 244-255, doi: 10.1007/ s00244-002-1175-6.

Tryland M., Thoresen S.I., Kovacs K.M. \& Lydersen C. 2006. Serum chemistry values of free-ranging white whales (Delphinapterus leucas) in Svalbard. Veterinary Clinical Pathology 35, 199-203, doi: 10.1111/j.1939-165x.2006. tb00114.x.

Urashima T., Sato H., Munakata J., Nakamura T., Arai I., Saito T., Tetsuka M., Fukui Y., Ishikawa H., Lydersen C. \& Kovacs K.M. 2002. Chemical characterization of the oligosaccharides in beluga (Delphinapterus leucas) and minke whale (Balaenoptera acutorostrata) milk. Comparative Biochemistry and Physiology B 132, 611-624, doi: 10.1016/ S1096-4959(02)00083-0.

Vacquié-Garcia J., Lydersen C., Ims R.A. \& Kovacs K.M. 2018. Habitats and movement patterns of white whales Delphinapterus leucas in Svalbard, Norway in a changing climate. Movement Ecology 6, article no. 21, doi: 10.1186/ s40462-018-0139-z.

Vacquié-Garcia J., Lydersen C. \& Kovacs K.M. 2019. Diving behaviour of adult male white whales, Delphinapterus leucas, in Svalbard, Norway. Polar Research 38, article no. 3605, doi: 10.33265/polar.v38.3605.

Vacquié-Garcia J., Lydersen C., Marques T.A., Aars J., Ahonen H., Skern-Mauritzen M., Øien N. \& Kovacs K.M. 
2017. Late summer distribution and abundance of ice-associated whales in the Norwegian High Arctic. Endangered Species Research 32, 59-70, doi: 10.3354/esr00791.

Vacquié-Garcia J., Lydersen C., Marques T.A., Andersen M. \& Kovacs K.M. 2020. First abundance estimate for white whales (Delphinapterus leucas) in Svalbard, Norway. Endangered Species Research 41, 253-263, doi: 10.3354/ esr01016.

Van Parijs S.M., Lydersen C. \& Kovacs, K.M. 2003. Sounds produced by individual white whales, Delphinapterus leucas from Svalbard during capture. Journal of the Acoustic Society of America 113, 57-60, doi: 10.1121/1.1528931.

VanWormer E., Mazet J.A.K., Hall A., Gill V.A., Boveng P.L., London J.M., Gelatt T., Fadely B.S., Lander M.E., Sterling J., Burkanov V.N., Ream R.R., Brock P.M., Rea L.D., Smith B.R., Jeffers A., Henstock M., Rehberg M.J., Burek-Huntington K.A., Cosby S.L., Hammond J.A. \& Goldstein T. 2019. Viral emergence in marine mammals in the North Pacific may be linked to Arctic sea ice reduction. Scientific Reports 9, article no. 15569, doi: 10.1038/ s41598-019-51699-4.

Villanger G.D., Kovacs K.M., Lydersen C., Haug L.S., Sabaredzovic A., Jenssen B. \& Routti H. 2020. Perfluoroalkyl substances (PFASs) in white whales (Delphinapterus leucas) from Svalbard-a comparison of levels in plasma sampled 15 years apart. Environmental Pollution 263, article no. 114497, doi: 10.1016/j.envpol.2020.114497.

Villanger G.D., Lydersen C., Kovacs K.M., Lie E., Skaare J.U. \& Jenssen B.M. 2011 . Disruptive effects of persistent organohalogen contaminants on thyroid function in white whales (Delphinapterus leucas) from Svalbard. Science of the Total Environment 409, 2511-2524, doi: 10.1016/j. scitotenv.2011.03.014.

Wolkers H., Bavel B., van Derocher A.E., Wiig Ø., Kovacs K.M., Lydersen C. \& Lindström G. 2004. Congener-specific accumulation and food chain transfer of polybrominated diphenyl ethers in two Arctic food chains. Environmental Science $\theta$ Technology 38, 1667-1674, doi: 10.1021/ es030448a.

Wolkers H., Lydersen C., Kovacs K.M., Burkow I. \& van Bavel B. 2006. Accumulation, metabolism, and foodchain transfer of chlorinated and brominated contaminants in subadult white whales (Delphinapterus leucas) and narwhals (Monodon monoceros) from Svalbard, Norway. Archives of Environmental Contamination and Toxicology 50, 69-78, doi: 10.1007/s00244-004-0257-z. 